\title{
Analisis Penetapan Nilai Jual Obyek Pajak Bumi dan Bangunan Sektor Perkebunan sebagai Upaya Peningkatan Sumber Pendapatan Daerah
}

\author{
Abdul Kadir * \\ Fakultas Ilmu Sosial dan Ilmu Politik, Universitas Medan Area, Indonesia \\ Diterima: Oktober 2018; Disetujui: Oktober 2018; Dipublish: Oktober 2018 \\ *Coresponding Email: abdulkadir@staff.uma.ac.id
}

\begin{abstract}
Abstrak
Tujuan dari tulisan ini untuk melakukan ekstensifikasi yaitu penggalian sumber penerimaan dari sektor perkebunan, melalui kebijakan berupa perubahan dalam menetapkan besarnya Nilai Jual Objek Pajak, Pajak Bumi dan Bangunan (NJOP PBB) berdasar variabel makro ekonomi dan produktivitas tanaman serta pengaruhnya terhadap Pendapatan Asli Daerah (PAD). Tulisan ini difokuskan pada NJOP dengan menggunakan data primer untuk menganalisis persepsi stakeholder dan data sekunder untuk analisis persamaan jalur. Hasil penelitian menunjukkan secara serentak variabel pertumbuhan ekonomi dan kepadatan penduduk berpengaruh nyata terhadap NJOP pada tingkat kepercayaan $95 \%$. Secara parsial variabel pertumbuhan ekonomi dan kepadatan penduduk berpengaruh nyata terhadap NJOP pada tingkat kepercayaan $95 \%$. Kemampuan variabel pertumbuhan ekonomi dan kepadatan penduduk secara bersama mampu memberikan penjelasan variasi NJOP sebesar 38,70 \%. Secara bersama variabel pertumbuhan ekonomi, kepadatan penduduk dan NJOP berpengaruh nyata terhadap PBB pada tingkat kepercayaan $95 \%$. Secara parsial pertumbuhan ekonomi, kepadatan penduduk dan NJOP berpengaruh nyata terhadap PBB pada tingkat kepercayaan $95 \%$. Kemampuan pertumbuhan ekonomi, kepadatan penduduk dan NJOP secara bersama mampu memberikan penjelasan variasi PBB sebesar $67,20 \%$. Secara serentak variabel pertumbuhan ekonomi, kepadatan penduduk, NJOP dan PBB berpengaruh nyata terhadap PAD pada tingkat kepercayaan $95 \%$. Secara parsial variabel pertumbuhan ekonomi, kepadatan penduduk, NJOP dan PBB berpengaruh nyata terhadap PAD pada tingkat kepercayaan $95 \%$. Variabel pertumbuhan ekonomi, kepadatan penduduk, NJOP dan PBB secara bersama mampu memberikan penjelasan variasi PAD sebesar 67,70\%.
\end{abstract}

Kata Kunci : Pertumbuhan Ekonomi, Kepadatan Penduduk, Nilai Jual Objek Pajak, Pajak Bumi dan Bangunan dan Pendapatan Asli Daerah.

\begin{abstract}
The purpose of this paper is to explore the sources of income from the plantation sector, through policies in the form of changes in determining the amount of Tax Object Sales Value, Land and Building Tax (PBB NJOP) based on macroeconomic variables and crop productivity as well as the effect on Regional Original Income (PAD) This paper focuses on NJOP by using primary data to analyze stakeholder perceptions and secondary data for path equation analysis. The results showed that simultaneously the variables of economic growth and population density had a significant effect on NJOP at a 95\% confidence level. Partially economic growth variables and population density have a significant effect on NJOP at a 95\% confidence level. The ability of economic growth variables and population density together can provide an explanation of the NJOP variation of 38.70\%. Together, the variables of economic growth, population density and NJOP have a significant effect on the United Nations at a 95\% confidence level. Partially economic growth, population density and NJOP have a significant effect on the United Nations at a 95\% confidence level. The ability of economic growth, population density and NJOP are jointly able to provide an explanation of the UN variation of $67.20 \%$. Simultaneously the variables of economic growth, population density, NJOP and PBB significantly affected PAD at 95\% confidence level. Partially, the variables of economic growth, population density, NJOP and PBB significantly affected PAD at 95\% confidence level. Variables of economic growth, population density, NJOP and PBB together are able to provide an explanation of PAD variation of $67.70 \%$.
\end{abstract}

Keywords: Economic Growth, Population Density, Tax Object Sales Value, Land and Building Tax, Regional Original Income. 
How to Cite: Kadir, A. (2018). Analisis Penetapan Nilai Jual Obyek Pajak Bumi dan Bangunan Sektor Perkebunan sebagai Upaya Peningkatan Sumber Pendapatan Daerah. Journal of Education, Humaniora and Social Sciences (JEHSS). 1 (1): 9-15.

\section{PENDAHULUAN}

Otonomi daerah dan desentralisasi memberi peluang kepada daerah untuk menyelenggarakan perekonomian secara otonom. Dalam penyelenggaraan otonomi daerah yang luas, nyata dan bertanggung jawab, diperlukan kewenangan dan kemampuan menggali sumber keuangannya sendiri, yang didukung oleh perimbangan keuangan antara Pemerintah Pusat dan Daerah.

Sumber dana merupakan faktor esensial dalam pelaksanaan otonomi daerah, karena tanpa dukungan dana yang cukup, kemampuan dalam mengatur urusan rumah tangga akan terganggu (Undangundang Nomor 32 Tahun 2004).

Sesuai ketentuan undang-undang, jenis sumber penerimaan daerah telah ditetapkan baik berupa pajak daerah maupun retribusi daerah, salah satunya penerimaan Pajak Bumi dan Bangunan (PBB) dari sektor perkebunan. Menurut data tahun 2005 bahwa potensi perkebunan di wilayah Sumatera Utara dengan luas areal 1.747.836,89 Ha meningkat 134.799 Ha atau naik 7,71\% dari luas areal tahun 2001 $(1.611 .462,06 \mathrm{Ha})$ dengan laju pertumbuhan 2,05\% per tahun. Jumlah produksi tahun 2005 sebesar 4.335.100,98 ton, meningkat jika dibandingkan dengan produksi tahun 2001 yang memiliki produksi 3.624.880,27 ton, laju pertumbuhan produksi rata-rata sebesar 2,19 \%. (Dinas Perkebunan, 2005).

Dalam perekonomian nasional, sumbangan PDRB perkebunan Sumatera Utara Tahun 2005 sebesar $25,9 \%$ dari PDB perkebunan nasional. Kondisi tersebut sebenarnya dapat menambah penerimaan daerah di Sumatera Utara jika komponen perkebunan dimasukkan sebagai bagian dari dana perimbangan bagi hasil sumber daya alam.

Insentif ekonomi perkebunan terhadap pemerintah kabupaten/kota dapat dilakukan dengan cara intensifikasi retribusi dan pajak tanpa bertentangan dengan perundang-undangan terutama dalam penetapan NJOP. Oleh karena itu perlu dilakukan kebijakan terhadap penetapan Nilai Jual Obyek PBB sektor perkebunan dalam pelaksanaan otonomi dan peningkatan sumber pendapatan daerah di Sumatera Utara, demi terciptanya dan terwujudnya peningkatan pembangunan daerah dan kesejahteraan masyarakat.

Pembangunan ekonomi ditujukan untuk menciptakan penghidupan masyarakat banyak negara yang bersangkutan makin makmur dan sejahtera, keduanya dalam artian ekonomi. Di samping itu, pembangunan ekonomi juga sering ditujukan untuk membuatstruktur ekonomi negara yang bersangkutan makin seimbang antara sektor ekonomi yang satu dan yang lain, terutama antara sektor pertanian termasuk di dalamnya perkebunan dan industri (Marsudi, 1994).

Menurut UU No. 12 Tahun 1985 tentang Pajak Bumi dan Bangunan, besarnya PBB sektor perkebunan diklasifikasikan untuk tanaman berumur panjang dan tanaman perkebunan berumur pendek adalah dengan diuraikan untuk pemanfaatan lahan (bumi) oleh perkebunan dengan kriteria : tanah yang belum/tidak ditanam, tanah yang sudah ditanam, tanaman belum menghasilkan dan tanaman menghasilkan serta tanah emplasmen.

Negara Indonesia yang memiliki begitu banyak sumber daya alam, salah satu diantaranya adalah sumber daya alam yang menghasilkan ekonomi berbasis perkebunan. Sesuai dengan aturan UU No. 32 Tahun 2004 dan UU No. 33 Tahun 2004 hendaknya memberikan kontribusi terhadap penerimaan pemerintah daerah. Dengan adanya penerimaan pemerintah daerah dari ekonomi berbasis perkebunan, dapat meningkatkan pengembangan wilayah.

Penetapan NJOP PBB sektor perkebunan melalui pendekatan sesuai kriteria pemanfaatan lahan (tanah) dengan variabel yang diamati sebagaimana sketsa kerangka konseptual penelitian. Lahan-lahan yang dikuasai pengelola perkebunan secara umum terdiri dari ketiga kategori antara lain adalah tanah yang belum/tidak ditanam, tanah yang sudah ditanam, tanah emplasemen, tanaman belum menghasilkan, tanaman menghasilkan, yang pada saat ini dikenakan pajak bumi bangunan yang sama, namun selayaknya kelima jenis lahan tersebut memiliki NJOP yang berbeda, karena lahan yang sedang menghasilkan berbeda nilai ekonominya, sehingga dengan pengkategorian lahan tersebut sesuai dengan fungsinya akan diperoleh NJOP yang berbeda dan berdampak terhadap PBB yang dikenakan, dengan perubahan $\mathrm{PBB}$ yang dikenakan maka disana terdapat bagian pusat dan daerah.

Pajak Bumi dan Bangunan yang dikenal dengan singkatan PBB adalah salah satu obyek pungutan pajak pusat, yang dibagihasilkan kepada daerah (provinsi dan kabupaten/kota). Dalam Pasal 2 Undangundang No. 12 Tahun 1985 yang telah dirubah dengan UU No. 12 Tahun 1994 menyebutkan bahwa obyek Pajak Bumi dan Bangunan adalah bumi dan/atau bangunan. Yang dimaksud dengan bumi adalah permukaan bumi dan tubuh bumi yang ada di bawahnya. Termasuk dalam pengertian bumi adalah tanah, termasuk tanah, pekarangan, sawah (Direktorat Jenderal Pajak dan Fakultas Ekonomi UNDIP, 1997). 
Pengaturan penerimaan PBB yang alokasinya diatur dalam UU No. 33 Tahun 2004 dengan rincian sebagai berikut:

$10 \%$ bagian pusat dari penerimaan pajak bumi dan bangunan dibagikan kepada seluruh daerah kabupaten/kota yang didasarkan atas realisasi penerimaan pajak bumi dan bangunan tahun anggaran berjalan, dengan perimbangan sebagai berikut :

$65 \%$ dibagikan secara merata kepada seluruh daerah kabupaten/kota;

$35 \%$ dibagikan sebagai insentif kepada daerah kebupaten/kota yang realisasi tahun sebelumnya mencapai/melampaui rencana penerimaan sektor tertentu, yang bertujuan untuk mendorong intensifikasi pemungutan pajak bumi dan bangunan.

$90 \%$ untuk daerah, yaitu dirinci sebagai berikut:

$16,2 \%$ untuk daerah provinsi;

64,8\% untuk daerah kabupaten/kota;

$9 \%$ untuk biaya pemungutan.

Klasifikasi obyek pajak sebagaimana dimaksud dalam undang-undang tersebut diatur oleh Menteri Keuangan yaitu berdasarkan Keputusan Menteri Keuangan No. 249/KMK.04/1993, obyek pajak digolongkan menjadi beberapa kelompok (sektor), yaitu : pedesaan, perkotaan, perkebunan, perhutanan non blok tebangan, perhutanan blok tebangan, dan pertambangan gas, dimana dalam pelaksanaannya mempedomani sistem dan prosedur dari mendaftar, pendataan, penetapan, penagihan, dan penyetoran pajak bumi dan bangunan ke kas negara melalui bank yang ditunjuk yang merupakan kewenangan Direktorat Jenderal Pajak (Departemen Keuangan Republik Indonesia) dengan jajarannya yaitu Direktorat PBB dan Kantor Pelayanan Pajak Bumi dan Bangunan di daerah, yang mempunyai keterkaitan kegiatan operasional di lapangan dengan unsur pemerintah provinsi dan kabupaten/kota.

\section{METODE PENELITIAN}

Metode penelitian yang digunakan adalah random sampling melalui cara purposive random sampling dengan sampel sebanyak 70 orang yang terdiri dari Instansi Dispenda, Dinas Perkebunan, Kantor Pelayanan PBB, Pengusaha Perkebunan, Kanwil Pajak, Perguruan Tinggi, Pemprovsu.

Untuk membuktikan hipotesis tersebut dilakukan dengan analisis data dengan cara uji non parametrik melalui uji Wilcoxon Match Pars dengan prosedur sebagai berikut:

Tidak ada perbedaan penetapan NJOP berdasarkan kebijakan dengan berdasarkan nilai 0 : produktivitas tanaman terhadap pendapatan asli daerah.

Ada perbedaan penetapan NJOP berdasarkan kebijakan dengan berdasarkan nilai produktivitas a : tanaman terhadap pendapatan asli daerah.

\section{Kriteria pengujian}

Ho diterima apabila jumlah jenjang yang terkecil $\mathrm{T}$ (dari perhitungan) lebih besar dari harga $\mathrm{T}$ table ( $\mathrm{T}$ harga Wilcoxon). Ha diterima apabila jumlah jenjang yang terkecil $\mathrm{T}$ (dari perhitungan) lebih kecil dari harga T table (T harga Wilcoxon)

\section{Kerangka Konseptual Penelitian}

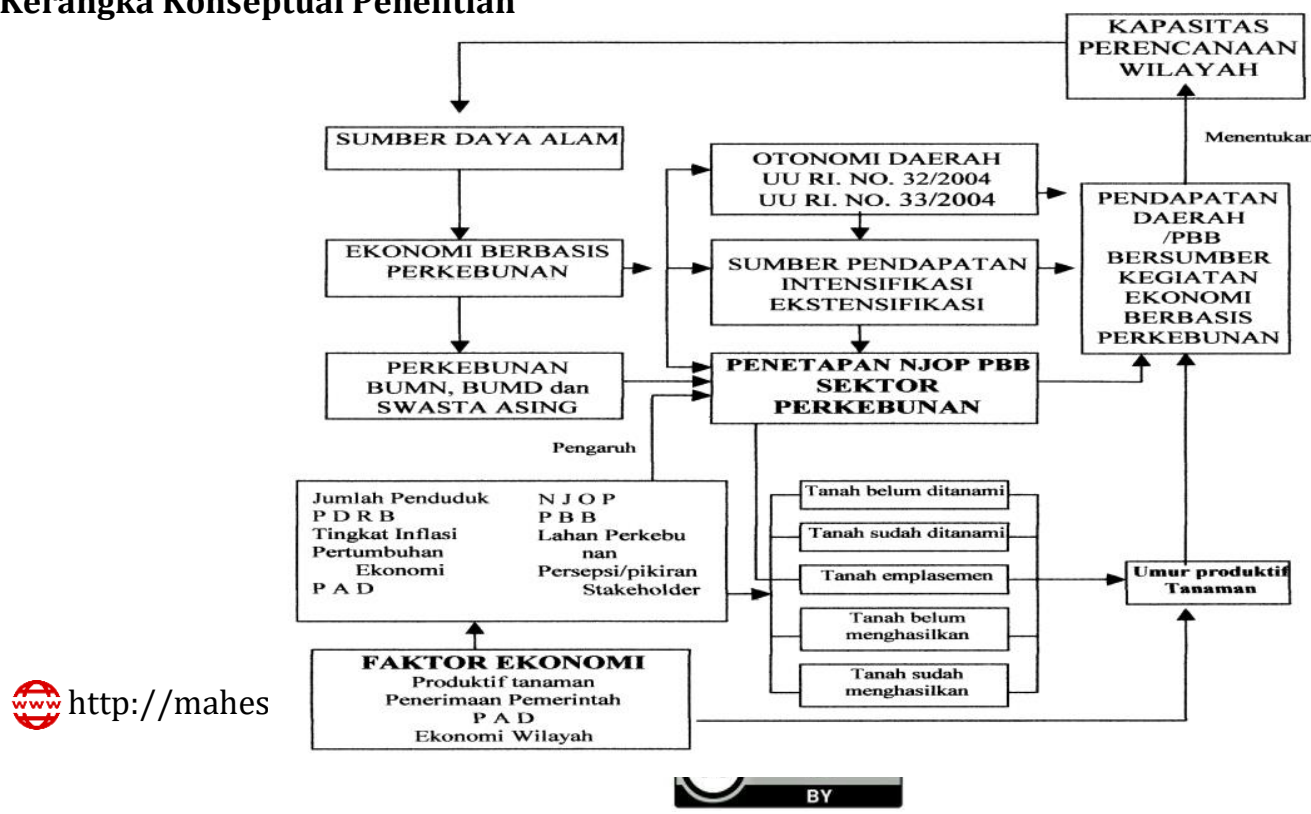




\section{HASIL DAN PEMBAHASAN}

Penerimaan pemerintah Provinsi Sumatera Utara yang secara umum berasal dari sumber-sumber sisa anggaran, pendapatan asli daerah, bagi hasil dari pusat, penerimaan lainnya, mengalami kenaikan secara bertahap setiap tahunnya.

PAD merupakan salah satu pemasukan yang menunjang/membiayai pelaksanaan pemerintahan, semakin baik pemerintahan suatu daerah maka akan semakin besar penerimaan dari sumber PAD, beberapa jenis sumber PAD yang dapat diandalkan dari Provinsi Sumatera Utara adalah seperti tertera pada tabel berikut:

Tabel 1. Besar dan Jenis Pendapatan Asli Daerah Provsu TA 2001 s/d 2005 (dalam rupiah)

\begin{tabular}{lccccc}
\hline Sumber PAD & \multicolumn{1}{c}{$\mathbf{2 0 0 1}$} & \multicolumn{1}{c}{$\mathbf{2 0 0 2}$} & \multicolumn{1}{c}{$\mathbf{2 0 0 3}$} & \multicolumn{1}{c}{$\mathbf{2 0 0 4}$} & \multicolumn{1}{c}{$\mathbf{2 0 0 5}$} \\
\hline Pajak Daerah & 388.017 .707 .444 & 584.089 .880 .257 & 861.973 .978 .668 & 1.081 .371 .912 .888 & 1.301 .137 .841 .983 \\
Retribusi Daerah & 15.448 .297 .654 & 7.127 .396 .655 & 16.925 .868 .688 & 23.756 .054 .666 & 18.852 .328 .406 \\
Laba BUMD & 4.627 .813 .791 & 5.055 .190 .250 & 5.880 .750 .000 & 7.056 .893 .000 & 8.523 .503 .000 \\
Pendapatan Lain-lain & 16.051 .676 .588 & 18.186 .914 .302 & 26.973 .317 .244 & 30.943 .866 .823 & 40.321 .487 .581 \\
\hline Jumlah & 423.075 .216 .370 & 614.459 .380 .864 & 908.262 .191 .068 & 1.143 .128 .727 .376 & 1.368 .835 .160 .970
\end{tabular}

Sumber: Dinas Pendapatan Provinsi Sumatera Utara, 2006

Realisasi penerimaan pajak daerah dari tahun ketahun mengalami kenaikan, pajak daerah pada tahun 2001 Rp. 388.017.707.444, tahun 2002 Rp. 584.089.880.257, tahun 2003 861.973.978.668, tahun 2004 1.081.371.912.888 sedangkan tahun 2005 Rp. 1.301.137.841.983. Sedangkan retribusi daerah terjadi penurunan pendapatan pada tahun 2002 Rp. 7.127.396.655 dan 2005 Rp. 18.852.328.406 dari tahun sebelumnya. Peningkatan pendapatan PAD selain terdapat di pajak daerah juga terdapat dilaba BUMD dan pendapatan lain-lain. Laba BUMD tahun 2001 Rp. 4.627.813.791, tahun 2002 Rp. 5.055.190.250, tahun 2003 Rp. 5.880.750.000, tahun 2004 Rp. 7.056.893.000 sedangkan tahun 2005 sebesar 8.523.503.000. Untuk pendapatan lain-lain tahun 2001 sebesar Rp. 16.051.676.588, tahun 2002 Rp. 18.186.914.302, tahun 2003 Rp. 26.973.317.244, tahun 2004 Rp. 30.943.866.823 dan terakhir sebesar Rp. 40.321.487.581.

Sedangkan realisasi penerimaan Pajak Bumi dan Bangunan Persektor di Propinsi Sumatera Utara dapat dilihat pada tabel berikut:

Tabel 2. Realisasi Penerimaan PBB Persektor Tahun 2001 - 2005

\begin{tabular}{llccccc}
\hline No & \multicolumn{1}{c}{ Sektor } & \multicolumn{1}{c}{2001} & \multicolumn{1}{c}{2002} & \multicolumn{1}{c}{2003} & 2004 & 2005 \\
\hline 1. & Pedesaan & 9.175 .324 .000 & 11.848 .633 .000 & 17.369 .193 .000 & 16.369 .193 .000 & 19.747 .435 .000 \\
2. & Perkotaan & 60.718 .617 .000 & 77.209 .834 .000 & 100.585 .871 .000 & 118.298 .659 .000 & 135.781 .045 .000 \\
& & 69.893 .941 .000 & 89.058 .467 .000 & 117.911 .772 .000 & 134.667 .852 .000 & 155.528 .480 .000 \\
3. & Perkebunan & 102.512 .451 .000 & 99.443 .931 .000 & 117.076 .831 .000 & 122.001 .020 .000 & 129.345 .859 .000 \\
4. & Perhutanan & 2.598 .093 .000 & 2.401 .576 .000 & 4.184 .376 .000 & 5.314 .077 .000 & 4.679 .118 .000 \\
5. & Pertambangan & 124.703 .144 .000 & 152.425 .717 .000 & 23.263 .817 .000 & 373.807 .366 .000 & 468.894 .352 .000 \\
\hline & Jumlah & 299.707 .629 .000 & 1343.329 .691 .000 & 462.436 .795 .000 & 635.790 .315 .000 & 758.447 .809 .000 \\
\hline
\end{tabular}

Sumber: Dinas Pendapatan Propinsi Sumatera Utara, 2006

Dari tabel tersebut dapat dilihat bahwa perkembangan penerimaan PBB, sejak tahun 2001 hingga tahun 2005 setiap tahunnya mengalami peningkatan, dari tahun 2001 ke tahun 2002 terjadi peningkatan 15\% dibandingkan penerimaan tahun 2001, demikian halnya penerimaan PBB tahun 2002 ke tahun 2003 meningkat sebesar 35\% dibanding penerimaan tahun 2002. Peningkatan penerimaan PBB tahun 2003 ke tahun 2004 adalah sebesar $37 \%$ dibandingkan penerimaan tahun 2003, serta penerimaaan pajak bumi dan bangunan dari tahun 2004 ke tahun 2005 sebesar $19 \%$ dibandingkan penerimaan tahun 2004.

Luas areal perkebunan di daerah Provinsi Sumatera Utara berdasarkan tahun selalu mengalami peningkatan, sehingga diharapkan akan mampu menghasilkan produksi perkebunan yang dapat menggerakkan perekonomian di Provinsi Sumatera Utara. Luas lahan perkebunan di Provinsi Sumatera Utara berdasarkan tahun seperti tertera pada tabel berikut: 
Tabel 3. Luas Lahan Perkebunan PTPN II. III. IV Tahun 2001 - 2005

\begin{tabular}{lllll}
\hline No & Tahun & $\begin{array}{l}\text { Tanaman Belum } \\
\text { Menghasilkan (Ha) }\end{array}$ & $\begin{array}{l}\text { Tanaman } \\
\text { Menghasilkan (Ha) }\end{array}$ & $\begin{array}{l}\text { Luas Tanaman } \\
\text { (Ha) }\end{array}$ \\
\hline 1 & 2001 & 35.409 & 256.988 & 366.441 \\
2 & 2002 & 47.904 & 312.050 & 372.753 \\
3 & 2003 & 54.392 & 300.507 & 374.660 \\
4 & 2004 & 42.122 & 301.930 & 357.834 \\
5 & 2005 & 63.126 & 257.834 & 337.812 \\
\hline
\end{tabular}

Sumber: Dinas Perkebunan Sumatera Utara 2006.

Berdasarkan data-data tersebut di atas, maka hampir pada setiap tahunnya lahan yang menghasilkan semakin luas. Hal ini berarti bertambahnya pemasukan bagi perkebunan tersebut, namun perlu diketahui bahwa PBB yang dikenakan pada perkebunan tersebut tidak berdasarkan keadaan lahan, sehingga besarnya pendapatan pengelola perkebunan tidak identik dengan peningkatan jumlah PBB yang diterima pemerintah.

Demikian halnya lahan-lahan perkebunan yang terdapat di Provinsi Sumatera Utara selalu mengalami perubahan setiap tahunnya, artinya penerimaan PBB yang berasal dari sektor perkebunan secara otomatis juga akan berubah-ubah setiap tahunnya. Besarnya luas lahan-lahan perkebunan yang terdiri dari perkebunan rakyat, Perkebunan Nasional (PTPN), Perkebunan Besar Swasta Nasional, Perkebunan Besar Swasta Asing, setiap tahunnya seperti tertera pada tabel berikut:

Tabel 4. Luas Lahan Perkebunan di Provinsi Sumatera Utara

\begin{tabular}{|l|l|c|c|c|c|c|}
\hline \multirow{2}{*}{ No } & \multirow{2}{*}{ Jenis lahan } & \multicolumn{5}{|c|}{ Tahun } \\
\cline { 3 - 7 } & & 2001 & 2002 & 2003 & 2004 & 2005 \\
\hline 1 & Menghslkan & 1.239 .468 & 1.249 .656 & 1.253 .882 & 1.259 .179 & 1.315 .575 \\
\hline 2 & Blm Mhslk & 201.894 & 203.855 & 204.242 & 205.165 & 214.291 \\
\hline 3 & Terlantar & 128.579 & 129.346 & 130.074 & 130.583 & 136.474 \\
\hline & Total & 1.569 .941 & 1.582 .857 & 1.588 .198 & 1.594 .907 & 1.666 .340 \\
\hline
\end{tabular}

Jika penerimaan daerah dikaitkan dengan perundangan tentang pengelolaan sumber daya alam dan sumber daya lainnya sesuai amanat Pasal 18 A ayat (2) UUD 1945, ditegaskan agar hubungan keuangan, pelayanan umum serta pemanfaatan sumber daya alam dan sumber daya lainnya antara pemerintah dan pemerintah daerah diatur dan dilaksanakan secara adil dan selaras berdasarkan undang-undang.

Selanjutnya dalam UU No. 12 Tahun 1985. Untuk dana bagi basil sumber daya alam telah dibatasi sektornya yaitu berasal dari Kehutanan, Pertambangan Umum, Perikanan, Minyak Bumi, Gas Bumi dan Panas Bumi, sedangkan sektor perkebunan tidak termasuk dalam komponen Sumber daya alam yang dapat di bagi hasilkan kepada daerah. Kebijakan tersebut juga tertuang di dalam ketentuan Undangundang Republik Indonesia No. 33 Tahun 2004 tentang Perimbangan Keuangan antara Pemerintah Pusat dan Pemerintah Daerah. Dengan adanya peraturan tersebut seolah-olah menutup kemungkinan daerah.

Namun perlu dicermati lebih mendalam isi dan makna yang terkandung di dalam UU No. 18 Tahun 2004 tentang Perkebunan, antara lain telah mengamanatkan bahwa perkebunan sebagai salah satu bentuk pengelolaan sumber daya alam di lakukan secara berencana, terbuka, terpadu, profesional dan bertanggung jawab. Perkebunan dalam hal ini secara nyata dimasukkan dalam kategori pengelolaan sumberdaya alam.

Penetapan PBB sektor perkebunan yang menetapkan hanya berdasarkan pada tanah tidak produktif, tanah yang tidak ditanami, tanah yang telah ditanami dan telah menghasilkan, tanah emplasmen, tanah yang tidak dimanfaatkan bangunan. Kondisi tanah yang ditanami dan telah menghasilkan ditambah dengan standar investasi tanaman membuka terjadinya polemik berkepanjangan, 
karena nilai investasi tumbuhan pada setiap daerah adalah berbeda-beda, serta semakin baik investasi yang ditanamkan tentu akan semakin baik hasil diperoleh pengelola perkebunan itu.

Peningkatan penerimaan Pajak Bumi dan Bangunan yang dimungkinkan meningkat adalah berdasarkan kondisi lahan perkebunan, jika diteliti secara mendalam keadaan lahan perkebunan berdasarkan tahun, seperti tertera pada tabel berikut:

Tabel 5. Komposisi Total Lahan Perkebunan Berdasarkan Tahun

\begin{tabular}{lllll}
\hline No. & Tahun & $\begin{array}{l}\text { Total Lahan } \\
\text { (Hektare) }\end{array}$ & $\begin{array}{l}\text { Peningkatan } \\
\text { (Hektare) }\end{array}$ & $\begin{array}{l}\text { Persentase } \\
\text { Peningkatan }\end{array}$ \\
\hline 1 & 2001 & 1.569 .941 & - & - \\
2 & 2002 & 1.582 .857 & 12.916 & 0,71 \\
3 & 2003 & 1.588 .198 & 5.341 & 0,32 \\
4 & 2004 & 1.594 .907 & 6.709 & 0,39 \\
5 & 2005 & 1.666 .340 & 71.433 & $\mathrm{I} 4,47$ \\
\hline
\end{tabular}

Sumber : Data Primer Olahan 2006

Peningkatan terbesar adalah pada tahun 2005 sebesar 4,47 \% dari luas lahan perkebunan tahun sebelumnya. Jika diteliti keadaan lahan berdasarkan kondisinya. Komposisi lahan yang telah menghasilkan seperti tertera pada tabel berikut:

Tabel 6. Komposisi Lahan yang Menghasilkan Berdasarkan Tahun

\begin{tabular}{lllll}
\hline No & Tahun & $\begin{array}{l}\text { Total Lahan } \\
\text { (Hektare) }\end{array}$ & $\begin{array}{l}\text { Peningkatan } \\
\text { (Hektare) }\end{array}$ & $\begin{array}{l}\text { Persentase } \\
\text { Peningkatan }\end{array}$ \\
\hline 2001 & 1.239 .468 & - & - \\
2002 & 1.249 .656 & 10.188 & 0,82 \\
2003 & 1.253 .882 & 4.226 & 0,33 \\
2004 & 1.259 .179 & 5.297 & 0,42 \\
2005 & 1.315 .575 & 56.396 & 4,45 \\
\hline \multicolumn{4}{c}{ Sumber : Data Primer Olahan 2006 }
\end{tabular}

Peningkatan luas lahan terbesar adalah pada tahun 2005 sebesar 4,45 \% atau setara dengan peningkatan luas sebesar 56,396 ha. Demikian halnya lahan perkebunan lainnya adalah lahan yang belum menghasilkan dengan komposisi berbeda setiap tahunnya, komposisi lahan yang belum menghasilkan sektor perkebunan seperti tertera pada tabel berikut:

Tabel 7. Komposisi Lahan yang Belum Menghasilkan

\begin{tabular}{lllll}
\hline No & Tahun & $\begin{array}{l}\text { Total Lahan } \\
\text { (Hektare) }\end{array}$ & $\begin{array}{l}\text { Peningkatan } \\
\text { (Hektare) }\end{array}$ & $\begin{array}{l}\text { Persentase } \\
\text { Peningkatan }\end{array}$ \\
\hline 1 & 2001 & 201.894 & - & - \\
2 & 2002 & 203.855 & 1.961 & $0,97 \%$ \\
3 & 2003 & 204.242 & 387 & $0,18 \%$ \\
4 & 2004 & 205.165 & 923 & $0,45 \%$ \\
5 & 2045 & 214.291 & 9.126 & $4,44 \%$ \\
\hline \multicolumn{5}{c}{ Sumber: Data Primer Olahan 2006 }
\end{tabular}

Peningkatan lahan yang belum menghasilkan terbesar berada pada tahun 2005 yaitu seluas 9.126 ha, serta komposisi lahan terlantar yang belum dikelola pihak perkebunan seperti tertera pada tabel berikut:

Tabel 8. Komposisi Lahan Terlantar Berdasarkan Tahun

\begin{tabular}{lllll}
\hline No & Tahun & $\begin{array}{l}\text { Total Lahan } \\
\text { (Hektare) }\end{array}$ & $\begin{array}{l}\text { Peningkatan } \\
\text { (Hektare) }\end{array}$ & $\begin{array}{l}\text { Persentase } \\
\text { Peningkatan }\end{array}$ \\
\hline 1 & 2001 & 128.579 & - & - \\
2 & 2002 & 129.346 & 767 & $0,59 \%$ \\
3 & 2003 & 130.074 & 428 & $0,33 \%$ \\
4 & 2004 & 130.583 & 509 & $0,39 \%$ \\
\hline
\end{tabular}


Vol. 1, No. 1, Agustus 2018: 9-15

DOI: https://doi.org/10.34007/iehss.v1i1.2

\begin{tabular}{|c|c|c|c|c|}
\hline 5 & 2005 & 136.474 & 5.891 & $4,51 \%$ \\
\hline
\end{tabular}

Lahan-lahan terlantar setiap tahunnya di Provinsi Sumatera Utara meningkat, pada tahun 2001 lahan terlantar seluas 128.579 ha menjadi seluas 136.474 ha pada tahun 2005, keadaan ini menunjukkan bahwa terjadi persiapan perluasan perkebunan setiap tahunnya.

Berdasarkan uraian data-data tersebut dapat disimpulkan bahwa luas lahan perkebunan yang telah menghasilkan mengalami perkembangan signifikan yaitu seluas 1.239.468 ha tahun 2001, menjadi seluas 1.315.575 ha pada tahun 2005, keadaan ini menunjukkan kepada kita jika penetapan PBB berdasarkan kondisi lahan maka dapat dipastikan penerimaan PBB sektor perkebunan akan meningkat, serta terjadi kecenderungan peningkatan setiap tahunnya karena tanaman yang belum menghasilkan pada saat ini, pada tahun yang akan datang kemungkinan akan menghasilkan.

Penetapan PBB sektor perkebunan berdasarkan kondisi lahan juga akan merangsang pengelola perkebunan untuk melakukan audit terhadap hasil perhektar dari perkebunannya, artinya lahan-lahan yang tidak menghasilkan secara ekonomis, secepatnya akan diganti dengan tanaman baru yang dapat diharapkan sesegera mungkin akan menghasilkan.

\section{SIMPULAN}

Terdapat peluang penetapan NJOP berdasarkan nilai produktif tanaman, hal ini didasarkan terbukanya perbedaan standar investasi tanaman perkebunan pada setiap daerah, sehingga selayaknya pada setiap daerah nilai investasi tersebut berbeda-beda, serta akan mengikuti perkembangan pasar, hal ini akan sangat menyulitkan sehingga diperlukan penetapan PBB tersebut berdasarkan kondisi produktifitas tanah. Penetapan NJOP berdasarkan kondisi produktif tanaman berpengaruh secara signifikan terhadap PAD hal ini ditunjukkan oleh harga z hitung 5,045 (harga mutlak) turnyata lebih besar dari 1,96. Jadi diperoleh pengaruh signifikan tentang penetapan NJOP berdasarkan kondisi produktif tanaman terhadap PAD. Hal ini ditunjukkan besarnya skor panjang jenjang positif sebesar 717,5. dan skor jenjang negatif sebesar 62,5. Pengaruh kebijakan penetapan NJOP melalui pendekatan kondisi lahan perkebunan terhadap peningkatan PBB, adalah memberikan pengaruh positif yaitu terjadinya kecenderungan peningkatan penerimaan PBB setiap tahunnya, serta semakin selektifnya pengelola perkebunan dalam mengelola lahan yang dimilikinya.

\section{DAFTAR PUSTAKA}

Dinas Pendapatan Daerah Provinsi Sumut. (2002). Studi Potensi Sumber PunRutan Daerah Terhadap Objek Atas Pemanfaatan dan Pengelolaan SDA yang Potensial di Provinsi Sumatera Utara. Medan..

Fauzi. (2001). Otonomi Daerah Sumberdaya Alam Lingkungan. Lapera Pustaka Utama. Yogyakarta.

Girsang, B. (2004). Wajah Pembangunan Perkehutanan di Provinsi Sumatera Utara Kedepan (Tahun 2005/2010).

Ismail, T. (2005). Pengaturan Pajak Daerah di Indonesia, Penerbit Pusat Evaluasi Pajak dan Retribusi daerah BAPEKKI. Dep Keuangan Republik Indonesia.

Kurniawan \& Agus P. (2004). Pajak Daerah dan Retribusi Daerah di Indonesia. Penerbit Bayu Media Publishing. Malang. Lubis, A. (2005). Otonomi Daerah: Suatu Anali.sis Tentang Pendapatan Daerah Kota Medan. Tesis. USU. Medan.

Marsudi. (1994). Ekonomi Pembangunan. Penerbit Gadjah Mada Press. Yogjakarta.

Undang-undang Republik Indonesia No. 12 Tahun 1985 tentang Pajak Bumi dan Bangunan.

Undang-undang Republik Indonesia No. 33 Tahun 2004 tentang Perimbangan Keuangan Antara Pemerintah Pusat dan Pemerintah Daerah.

Undang-undang Republik Indonesia No. 18 Tahun 2004 tentang Perkebunan.

Peraturan Pemerintah No. 48 Tahun 1997 tentang Penetapan Besarnya Nilai Jual Kena Pajak untuk Penghitungan PBB.

Peraturan Pemerintah No. 74 Tahun 1998 tentang Penetapan Besarnya Nilai Jual, Kena Pajak untuk Penghitungan Pajak Bumi dan Bangunan. 